\section{Oral and Maxillofacial Trauma in Brazilian Children and Adolescents}

Livia Aguiar Bregagnolo1, Janete Cinira Bregagnolo², Fernando da Silveira², André Luiz Bérgamo ${ }^{3}$, Liliane Nascimento de Santi ${ }^{4}$, Marlívia Gonçalves de Carvalho Watanabe ${ }^{2}$
'School of Dentistry, USP - University of São Paulo, São Paulo, SP, Brazil 2Ribeirão Preto School of Dentistry, USP - University of São Paulo, Ribeirão Preto, SP, Brazil ${ }^{3}$ Private Practice, Ribeirão Preto, SP, Brazil

${ }^{4}$ School of Dentistry, UFPA - Federal University of Pará, Belém, Pará, Brazil

Correspondence: Profa. Dra. Marlívia Gonçalves de Carvalho Watanabe, Avenida do Café S/N, 14040-904 Ribeirão Preto, SP, Brasil. Tel.: +55-16-3602-4039. e-mail: marlivia@forp.usp.br that resulted in police records, in children and adolescents aged between 0 and 16 years during a period of 5 years. Among the 28,200 reports analyzed, 463 were included in the study. The men:women ratio observed was 1.6:1 and the most prevalent age range was between 15-16 years (44.40\%). Most trauma cases resulted from physical assault $(64.50 \%)$ and culminated in soft-tissue lesion (80.36\%). Excoriations (28.64\%) leaded as the most frequent type of lesion, and the maxillary region $(22.63 \%)$ was the most common location of injury. The most common type of dental lesion was dental trauma $(54.76 \%)$, and bone fractures prevailed in the nasal region (36.7\%). The findings of this survey may contribute to plan and execute preventive measures as well as to guide curative measures aimed at this population group.
Key Words: dentoalveolar trauma, soft-tissue, violence, maxillofacial trauma.

\section{Introduction}

The face is a very important region of the body, since it centers physiological and sensory functions. Facial injury may be a life threat, causing the obstruction of airways or severe hemorrhage. Furthermore, it may also cause pain, impaired facial expression and permanent disorder of functions such as sight, smell, mastication and deglutition, as well as psychological disorders. Harm to an individual's aesthetics and function has a significant effect on his/her personal and professional relationships.

The oral and maxillofacial regions are frequent targets of trauma. Together, oral and maxillofacial injuries correspond to $35 \%$ of the injuries in the whole body in the group between 0 and 6 years of age and 14\% in the group between 7 and 15 years. In the former group, this result may be attributed, among other factors, to the fact that the head of children at early age consists of an area proportionally larger and heavier than in adults, as well as to their decreased ability to protect their face when compared to adults (1).

External causes, such as violence and accidents, are constantly indicated among the causes for oral and maxillofacial trauma in children and adolescents. Among violence victims, there has been an increase in the incidence of trauma in these regions and in the proportion of young adults presenting these injuries $(1,2)$.

The occurrence of dental trauma resulting from domestic violence was studied in a group of Brazilian children and adolescents, and a predominance of avulsions $(33.3 \%)$ and fractures (66.6\%) was observed (3).

Literature has demonstrated a lack of studies approaching, simultaneously, different etiologies, types and locations of oral and maxillofacial trauma in children and adolescents. The perspective of developing a study of this nature may contribute to approach this population group more comprehensively, in both health and social aspects.

The purpose of this study was to describe the characteristics of oral and maxillofacial trauma in Brazilian children and adolescents in a study period of 5 years.

\section{Material and Methods}

A cross-sectional epidemiological study was developed to obtain the frequency of oral and maxillofacial traumas, based on forensic reports of a police institution in a medium-size municipality $(600,000$ inhabitants) in Brazil, for a period of 5 years.

The study comprised reports with the following characteristics: (a) crimes that occurred and were registered in the municipality during a time span of 5 years; (b) individuals aged 16 years or younger, regardless of gender; (c) trauma located in the oral and maxillofacial regions.

The study was developed by analyzing approximately 28,200 forensic reports, and recording the information on a specific form containing fields regarding the characteristics of the trauma (type and location), the individual (gender, ethnicity and age) and the occurrence (etiology).

Incomplete fields in the analyzed forms were grouped with the code "unknown". In tables where there was more than one field with less than $1 \%$ of the cases, these fields were grouped with the code "others".

The statistical analysis was developed with the use of descriptive analysis. The characteristics and the relationship 
between the different types of soft-tissue lesions were analyzed by the Chi-square test, considering an alpha of 0.05 , using the CDC public domain Epi-Info software. The study was approved by the institutional Ethics Committee (Process \#2003.1.863.58.5).

\section{Results}

A total of 463 cases of oral and maxillofacial trauma were registered in the age range between 0 and 16 years, in the period of 5 years. In general, it was observed that the number of cases increased year after year. Most of the victims $(61.30 \%)$ were men and the men:women ratio was 1.6:1.

There was an increase in the number of cases as the age advanced. The age range with the lowest proportion was that of children under 5 years of age, accountable for $10.20 \%$ of the cases, and the most frequent range was that of young adults between 15-16 years of age, presenting $44.40 \%$ of the cases. The most common ethnicity was white, with $70.40 \%$ of the cases, followed by pardo $(12.10 \%)$ and black individuals (5.40\%). Physical assault was the most common etiology in all years, taking place in $64.50 \%$ of the cases, followed by traffic accidents (13.20\%), infractions $(7.60 \%)$, firearm (3.50\%) and abuse (2.20\%) (Table 1).

A characteristic was quite similar among the etiologies of oral and maxillofacial trauma in all the age ranges studied, with physical assault and traffic accidents being $\rightarrow$ always the two most frequent ones, and the others varying at each range (Fig. 1).

There were 555 injuries registered, with a mean of 1.2 per child. The most frequently observed type of trauma was soft-tissue lesion (80.36\%), followed by dental trauma (7.75\%) and bone fracture (4.33\%) (Table 2). Excoriation (28.64\%), edema (23.94\%), contused wound (15.88\%) and ecchymosis (14.32\%) were the most common types of soft-tissue lesions (Table 2). According to Figure 2, the location of this type of trauma was more frequent in the maxillary (22.63\%), oral (21.21\%) and nasal (18.46\%) areas. The dental injuries occurred in $7.75 \%$ of traumas and their most common type was dental trauma (54.76\%), followed by dental avulsion (45.24\%). Bone fracture occurred in $4.33 \%$ of the cases, with nasal (36.67\%), maxillary (26.67\%) and mandible (20.0\%) fractures being more frequent, as presented in Figure 3.

The relationships between soft-tissue lesion and dental injury $(p<0.001)$ and between soft-tissue lesion and facial bone fracture $(p<0.001)$ were considered statistically significant, contrary to the relationships between dental injury and facial bone fracture.

The relationships between the two main etiologies and the types of lesion were also evaluated. The relationships between traffic accidents and soft-tissue lesion $(p<0.001)$, and dental injury $(p<0.001)$ were considered statistically significant, contrary to the relationships between physical assault and these types of lesion (Table 3).

Table 1. Characteristics of the cases

\begin{tabular}{lcc}
\hline & Number of cases & $\%$ \\
\hline Year & 68 & 14.70 \\
$1^{\circ}$ & 96 & 20.70 \\
$2^{\circ}$ & 101 & 21.80 \\
$3^{\circ}$ & 84 & 18.20 \\
$4^{\circ}$ & 114 & 24.60 \\
$5^{\circ}$ & 463 & 100.00 \\
Total & & \\
Gender & & \\
Male & 284 & 38.70 \\
Female & 179 & 100.00 \\
Total & 463 & \\
male:female ratio & $1.6: 1$ &
\end{tabular}

Age group (years)

$\begin{array}{lcc}<5 & 47 & 10.20 \\ 5-9 & 66 & 14.30 \\ 10-14 & 144 & 31.10 \\ 15-16 & 206 & 44.40 \\ \text { Total } & 463 & 100.00\end{array}$

Ethnic group

$\begin{array}{lcc}\text { White } & 326 & 70.40 \\ \text { Black } & 25 & 5.40 \\ \text { Brown } & 56 & 12.10 \\ \text { Unknown } & 56 & 12.10 \\ \text { Total } & 463 & 100.00\end{array}$

Etiology

$\begin{array}{lcc}\text { Physical aggression } & 299 & 64.50 \\ \text { Traffic accident } & 61 & 13.20 \\ \text { Infractional act } & 35 & 7.60 \\ \text { Gunshot wound } & 16 & 3.50 \\ \text { Maltreatment } & 10 & 2.20 \\ \text { Other causes } & 21 & 4.50 \\ \text { Unknown } & 21 & 4.50 \\ \text { Total } & 463 & 100.00\end{array}$




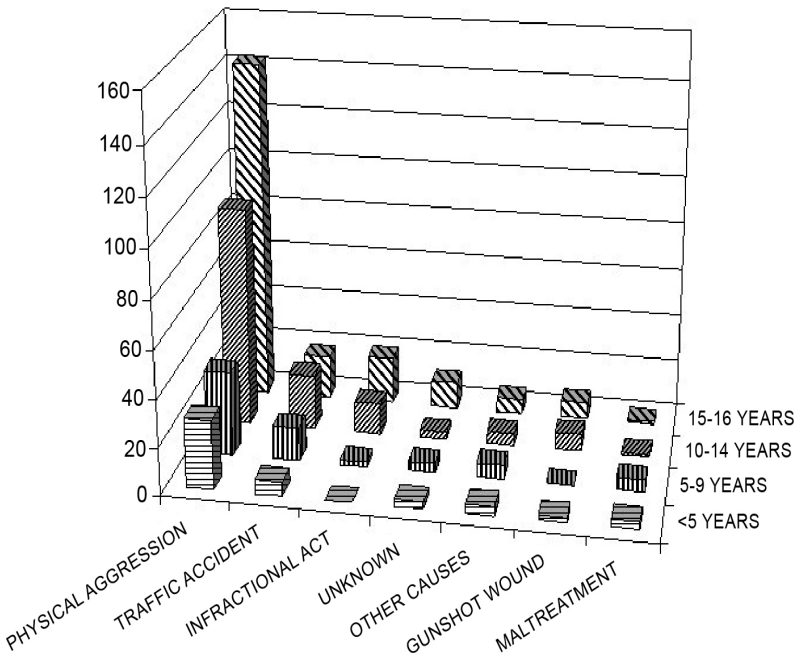

Figure 1. Etiology of the injury regarding the age group.

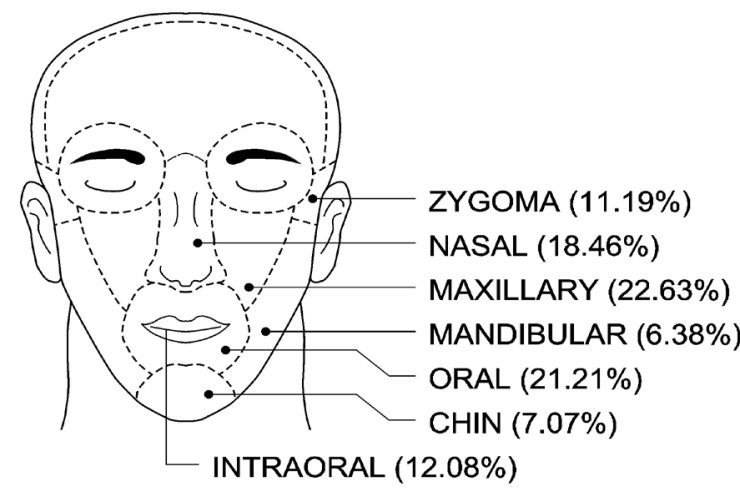

FACIAL INEXPLICIT (0.98\%)

Figure 2. Types of trauma.

Table 2. Type of soft tissue injury

\begin{tabular}{lcc}
\hline Type of soft tissue injury & $\mathrm{N}$ & $\%$ \\
\hline Excoriation & 128 & 28.64 \\
Edema & 107 & 23.94 \\
Bruised cut & 71 & 15.88 \\
Ecchymosis & 64 & 14.32 \\
Hematoma & 21 & 4.70 \\
Cicatrice & 18 & 4.03 \\
Bruise & 12 & 2.68 \\
Intraoral soft tissue injury & 12 & 2.68 \\
Facial lesion & 8 & 1.79 \\
Cut & 6 & 1.34 \\
Total & 441 & 100.00 \\
\hline
\end{tabular}

\section{Discussion}

In this study, the characteristics of oral and maxillofacial trauma in children between 0 and 16 years of age were analyzed. Data were collected from police records of body lesion examinations, and must be interpreted as the number of cases reported.

Regarding gender, studies in the world literature demonstrate that men are more affected than women, and this predominance keeps constant throughout time (4). The identified men:women ratio of 1.6:1 agrees with that observed in several studies, in which it varied between 1.6:1 and 3.3:1 (1,4-8). Souza (9) found a significantly higher ratio than most of the studies mentioned (4.2:1), still with the predominance of men, and this difference may have been found due to the sample size of only 42 patients. In another study addressing exclusively child abuse, the ratio was 1:1.6. According to several authors, boys obtain freedom earlier to perform activities without the direct

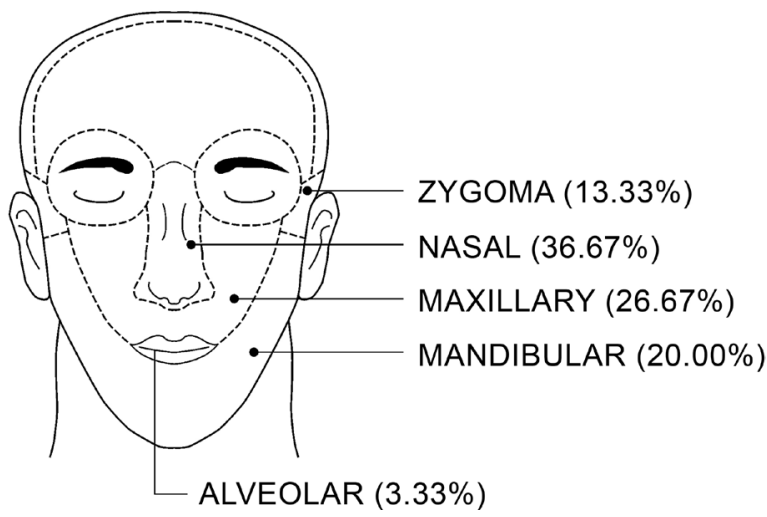

Figure 3. Localization of bone fractures.

Table 3. Correlation between different types of trauma and the two main etiologies and the types of trauma (Chi-square test)

Correlation between $\quad$ Significance NS

Soft tissue injury and dental injury

$\mathrm{p}<0.001$

Soft tissue injury and bone fracture

$\mathrm{p}<0.001$

Dental injury and bone fracture

Physical aggression and soft tissue injury

Physical aggression and dental injury

Physical aggression and bone fracture

$\mathrm{X}$

Traffic accident and soft tissue injury

$p<0.001$

Traffic accident and dental injury

$\mathrm{p}<0.001$

Traffic accident and bone fracture

$p=0.0219$

NS: No significance. 
supervision of an adult, are more active, engage in more dangerous activities, practice more impact sports, have a more adventurous nature and are more aggressive than girls, participating in fights and, consequently, suffering more aggressions (9).

Several authors have observed that the occurrence of maxillofacial trauma increases gradually as people age (6). This statement may be due to the fact that younger children spend more time under the protection of their family and, therefore, are less exposed to accidents or traumas compared with the older population. As the children grow, the social environment changes and their contact with the exterior world increases (6). The age range between $15-16$ years (44.4\%) was the most frequent in the present study, the same reported by Bamjee et al. (5) and similar to those of other authors, who referred to a higher frequency in the age range between 13 and 17 years (8) and between 13 and 18 years (4). Other authors found different prevalent age ranges. Gulinelli et al. (11) reported a prevalence (20.3\%) of 16-20-year-old age group. Guedes et al. (12) reported the age group of 6 to 10 year (31.52\%), which might have occurred because the study comprised a wide age range from children to older adults (1) or because the study was conducted in hospitals and dental or medical emergency services, which means that etiologies not observed in this study, such as sports-related falls or accidents $(1,2,13)$, were included. In the literature, there is a divergence in the standardization of limit ages for age ranges, which complicates the comparison between the several epidemiological studies (9).

The white ethnicity was the most frequent in the present study followed by pardo, as reported elsewhere (4). These results indicate similar proportions to the data observed, considering that the distribution of the population by ethnicity revealed a proportion of $69.75 \%$ of white, followed by $22.83 \%$ of pardo and $6.36 \%$ of black people (14). The racial factor is susceptible to changes in its epidemiological characteristics according to the culture and region evaluated (4). The evaluation of this population indicator is significantly important, since racial segregation may lead to social and economical discriminations in society.

In this study, the most common etiologies were physical assault and traffic accidents. Studies developed in Sweden (1), South Africa (5) and United Kingdom (2) obtained similar results: i.e., physical assault was also the most common etiology for oral and maxillofacial trauma, also followed by traffic accidents $(5,15)$ in some cases. In Brazil, Ferreira et al. (16), in a 10-year retrospective study, observed traffic accidents as the main etiology (53\%). Souza (9) found the most common etiology to be falls and traffic accidents, in equal percentage, and also observed that etiologic factors may be related with age, considering that younger individuals are exposed to traumas of lesser intensity, increasing their exposure as years go by. Gassner et al. (17) also observed a constant relationship between the etiologies in all studied years and age ranges. According to Shaikh and Worral (2), factors such as geographical location, socioeconomic status, family or cultural environment influence etiology and the incidence of facial trauma.

The most frequent type of lesion in the present study was soft-tissue injury, similar to the findings of several studies $(7,8,13,17)$, but different from another one (1) that reported dental injuries as the most common type of trauma. Silva et al. (15) separated children (up to 11 years of age) and adolescents ( 12 to 18 years of age) by age range and verified that, the former presented a prevalence of dental lesions, whereas among the latter, soft-tissue lesions prevailed.

The most common type of soft-tissue lesion was excoriation, with predominance in the maxillary region, different from other studies, which found lacerations $(7,17)$ and contusion in the lips and oral mucosa $(8)$ to be the most common type.

Regarding dental injury, dental trauma was the most common type, different from the result obtained by Gassner et al. (7). Munante Cardenas et al. (4) found a prevalence of tooth avulsion as dental injury. Spring and Cote (18) reported that dentoalveolar factures were more frequent, which are often excluded from statistical studies on facial trauma. In this study, nasal fractures were also more common, in agreement with the findings of Anderson (19). In the opposite direction, several studies observed mandible fractures as the most frequent $(4-6,9)$. Keniry (20) states that the mandible is the bone most commonly affected by fractures, whereas those of the zygoma are rare.

Traumatic dental injuries occur with great frequency in preschool, school-age children, and young adults comprising $5 \%$ of all injuries for which people seek treatment $(1,21)$. A 12-year review of the literature reports that $25 \%$ of all school children experience dental trauma and $33 \%$ of adults have experienced trauma to the permanent dentition, with the majority of injuries occurring before age nineteen (22).

A study with children and adolescents found that despite the high incidence of facial trauma, the occurrence of fractures was rare (9). This may be explained by the relative elasticity of the child skeleton and the fact that the children's bone morphology is different from the bone tissue in the adult, their cortical bone portion is thin and their medullary bone portion is thick, which generates a model of great elasticity to the bone and resistance to fracture $(9,18)$. Another hypothesis would be the presence of the buccal fat pad that protects the zygomatic region, reducing the frequency of facial fractures in children (23). In the present study, the bone fractures were not related 
with the injury of teeth.

From the point of view of the main causes or situations that led to buccal-maxillofacial trauma, it was observed that traffic accidents presented a more frequent relationship with soft-tissue lesions and dental injury.

According to these findings, it is possible to conclude that most trauma cases in children and adolescents derived from physical assault and resulted in soft-tissue lesion, in the form of excoriation in the maxillary region. The information obtained in this study may assist the planning and execution of preventive measures and guide curative measures aimed at this population group.

\section{Resumo}

Crianças e adolescentes frequentemente são vítimas de trauma nas regiões oral e maxilofacial. 0 objetivo deste estudo foi determinar as características do trauma na região oral e maxilofacial que resultaram em registros policiais, em crianças e adolescentes na faixa etária de 0 a 16 anos, por um período de 5 anos. Dos 28.200 laudos avaliados, 463 foram incluídos na pesquisa. A taxa homem:mulher observada foi de 1,6:1 e a faixa etária de maior ocorrência foi a de $15-16$ anos $(44,40 \%)$. A maioria dos casos de trauma foi decorrente de agressão física $(64,50 \%)$ e resultou em lesão de tecido mole $(80,36 \%)$. Entre os tipos mais frequentes, destacam-se as escoriações $(28,64 \%)$ e quanto à localização, a região maxilar (22,63\%). 0 tipo de lesão dental mais comum foi trauma dental $(54,76 \%)$, e as fraturas ósseas predominaram nas regiões nasal $(36,7 \%)$. Os resultados encontrados podem auxiliar no planejamento e execução de medidas preventivas e direcionar medidas curativas dirigidas a este grupo populacional.

\section{Acknowledgements}

This study was developed with the support of the São Paulo Research Foundation (FAPESP).

\section{References}

1. Petersson $E E$, Andersson L, Sörensen S. Traumatic oral vs non-oral injuries. Swed Dent J 1997;21:55-68.

2. Shaikh ZS, Worral SF. Epidemiology of facial trauma in a sample of patients aged 1-18 years. Injury 2002;33:669-671.

3. Garbin CAS, Queiroz APDG, Rovida TAS, Garbin AJl. Occurrence of traumatic dental injury in cases of domestic violence. Braz Dent J 2012;23:72-76

4. Munante-Cardenas JL, Olate $\mathrm{S}$, Albergaria-Barbosa Jr., de Moraes M, Moreira RWF. Pattern and treatment of facial trauma in pediatric and adolescent patients. J Craniofac Surg 2011;22:1251-1255.

5. Bamjee $Y$, Lownie JF, Cleaton-Jones PE, Lownie MA. Maxillofacial injuries in a group of South Africans under 18 years of age. $\mathrm{Br} J$ Oral
Maxillofac Surg 1996;34:298-302.

6. Lida $S$, Matsuya T. Paediatric maxillofacial fractures: their aetiological characters and fracture patterns. J Craniomaxillofac Surg 2002;30:237241.

7. Gassner R, Tuli T, Hächl 0 , Moreira R, Ulmer H. Craniomaxillofacial trauma in children: a review of 3,385 cases with 6,060 injuries in 10 years. J Oral Maxillofac Surg 2004;62:399-407.

8. Cavalcanti AL. Maxillo facial injuries in victims of violence at school environment. Ciênc Saúde Coletiva 2009;14:1835-1842.

9. Souza DFM, Santili C, Freitas RR, Akkari M, Figueiredo MJPSS. Epidemiology of children's facial fractures in the emergency room of a tropical metropolis. Acta Ortop Bras 2010;18:335-338.

10. da Fonseca MA, Feigal RJ, Ten Bensel RW. Dental aspects of 1248 cases of child maltreatment on file at a major county hospital. Pediatr Dent 1992;14:152-157.

11. Gulinelli JL, Saito CT, Garcia-Júnior IR, Panzarini SR, Poi WR, Sonada CK, et al.. Occurrence of tooth injuries in patients treated in hospital environment in the region of Araçatuba, Brazil during a 6-year period. Dent Traumatol 2008;24:640-644.

12. Guedes AO, Alencar AHG, Lopes LG, Pécora JD, Estrela C. A retrospective study of traumatic dental injuries in a Brazilian dental urgency service. Braz Dent J 2010;21:153-157.

13. Hussain $K$, Wijetunge $D B$, Grubnic $S$, Jackson IT. A comprehensive analysis of craniofacial trauma. J Trauma 1994;36:34-37.

14. IBGE. The Brazilian Institute of geography and statistics. Census 2010. [accessed in 04 jun 2012]. <http://www.ibge.gov.br/cidadesat/xtras/ perfil.php? $r=2 \&$ codmun $=354340>$.

15. Silva CJP, Ferreira EF, Paula LPP, Naves MD, Vargas AMD, Zarzar PMP. A. The urban violence against children and adolescents in Belo Horizonte: a story told through the maxillofacial traumas. Physis 2011;21:11031120.

16. Ferreira PC, Amarante JM, Silva AC, Pereira JM, Cardoso MA, Rodrigues JM. Etiology and patterns of pediatric mandibular fractures in Portugal: a retrospective study of 10 years. J Craniofac Surg 2004;15:384-391.

17. Gassner R, Tuli T, Hächl O, Rudisch A, Ulmer H. Cranio-maxillofacial trauma: a 10 year review of 9543 cases with 21067 injuries. J Cranio Maxillofac Surg 2003;31:51-61.

18. Spring PM, Cote DN. Pediatric maxillofacial fractures. J La State Med Soc 1996;148:199-203.

19. Anderson PJ. Fractures of the facial skeleton in children. Injury 1995;26:47-50.

20. Keniry AJ. A survey of jaw fractures in children. Br J Oral Surg 1970;8:231-236.

21. Andreasen JO, Andreasen FM, Andersson L. Textbook and color atlas of traumatic injuries to the teeth, 4th ed. Oxford, UK: Wiley-Blackwell; 2007.

22. Glendor U. Epidemiology of traumatic dental injuries - a 12 year review of the literature. Dent Traumatol 2008;24:603-611.

23. Koltai PJ, Rabkin D. Management of facial trauma in children. Pediatr Clin North Amer 1996;43:1235-1275. 